\title{
Purification and characterization of an extracellular laccase from solid-state culture of Pleurotus ostreatus HP-1
}

\author{
Hardik Patel · Shilpa Gupte · Mayur Gahlout • \\ Akshaya Gupte
}

Received: 16 January 2013 / Accepted: 6 March 2013/Published online: 16 March 2013

(c) The Author(s) 2013. This article is published with open access at Springerlink.com

\begin{abstract}
A native isolate of Pleurotus ostreatus HP-1 (Genbank Accession No. EU420068) was found to have an excellent laccase producing ability. The extracellular laccase was purified to electrophoretic homogeneity from copper sulphate induced solid-state fermentation medium by ammonium sulphate precipitation and ion-exchange chromatography. The enzyme was determined to be monomeric protein with an apparent molecular mass of $68,420 \mathrm{kDa}$, and an isoelectric point $(\mathrm{p} I)$ of 3.5 . The inductively coupled plasma spectroscopy showed a presence of iron, zinc and copper in the purified enzyme. The absorption spectrum in the range of $200-700 \mathrm{~nm}$ showed the maximum absorption at $610 \mathrm{~nm}$ characteristic of fungal laccase and corresponding to the presence of type I copper atom. The laccase was stable at different temperatures up to $70{ }^{\circ} \mathrm{C}$ and retained $61 \%$ activity at $50{ }^{\circ} \mathrm{C}$. The enzyme reaction was inhibited by cysteine; sodium azide and EDTA. The enzyme oxidized various known laccase substrates, its lowest $K_{\mathrm{m}}$ value being for ortho-dianisidine and highest $K_{\text {cat }}$ and $K_{\text {cat }} / K_{\mathrm{m}}$ for ABTS. The purified laccase exhibited different $\mathrm{pH}$ optima for different substrates. The $\mathrm{N}$-terminal sequence did not show any similarity with $\mathrm{N}$-terminal sequence of other species of genera Pleurotus.
\end{abstract}

Keywords Laccase - Pleurotus ostreatus - Purification · $\mathrm{N}$-terminal sequencing $\cdot$ ABTS

H. Patel · S. Gupte · M. Gahlout · A. Gupte $(\bowtie)$ Department of Microbiology, N. V. Patel College of Pure and Applied Sciences, Vallabh Vidyanagar 388 120, Gujarat, India

e-mail: akshaya_gupte@hotmail.com

\section{Introduction}

Laccases (benzenediol: oxygen oxidoreductase, E.C. 1.10.3.2) are multinuclear copper-containing enzymes that catalyse the oxidation of a variety of phenolic and inorganic compounds, with the concomitant reduction of oxygen to water. Laccases are widely distributed in nature and have also been detected in plants, insects, bacteria and especially in fungi (Majeau et al. 2010). These oxidative enzymes are particularly abundant in white-rot Basidiomycete fungi, which are capable of degrading lignin in vivo. Fungal laccase are known to catalyze the polymerization, depolymerization and methylation and/or demethylation of phenolic compounds (Leonowicz et al. 1985). Laccases are either monomeric or multimeric copper containing glycoprotein's, which may exhibit additional heterogeneity because of variable carbohydrate content or difference in copper content or because they are expressed as the products of multiple genes (Dahiya and Singh 1998). The implications of laccases in biotechnology follow from the foregoing characteristics from their already demonstrated effectiveness as agents for selected bioremediation, catalysts for regiospecific biotransformations, participants in biosensor constructs, and from their considerable retention of activity in organic solvents (Slomczynski et al. 1995). Fungal laccases have ability in the degradation of toxic fungal metabolite, such as aflatoxin $\mathrm{B} 1$, in ethanol production, manufacturing of cream and wine clarification. These characteristics have led to laccases being qualified as "eco-friendly" enzymes (Alberts et al. 2009; Lu et al. 2007).

The purification of a laccase is an essential step for the determination of accurate kinetic parameters due to the possible presence of compounds from the host fungus that may act as natural mediators, or the presence of similar 
enzymes that may exhibit significantly different reaction kinetics (Rittstieg et al. 2003). The most commonly used method for laccase purification is salt elution from an anion-exchange resin, probably due to the higher stability of laccase at neutral to slightly alkaline $\mathrm{pH}$, as well as the isoelectric point $(p I)$ of laccases.

In the present work, a systematic study was conducted to purify and characterizes the laccase produced by Pleurotus ostreatus HP-1. Properties investigated in this study included molecular mass, isoelectric point, the effect of $\mathrm{pH}$, temperature, inhibitor on enzyme activity, thermal stability and substrate specificity. The appropriate knowledge about structural and functional properties of $P$. ostreatus HP-1 laccases will further help in the elucidation of physiological function of this enzyme.

\section{Materials and methods}

\section{Chemicals}

The 2,2'-azino-bis-3-ethyl-benzthiazoline-6-sulphonic acid (ABTS) and Guaiacol were purchased from Sigma Chemical (St. Louis, USA). The 2,6-dimethoxyphenol was purchased from Lancaster (Lancs, UK). The silver nitrate, sodium carbonate, acrylamide, bis-acrylamide, acetone, formaldehyde were procured from Qualigens (India). All other chemicals were used of analytical grade and of highest purity available.

\section{Ammonium sulphate precipitation of laccase}

For the production of laccase from $P$. ostreatus HP 1 (Genbank Accession No. EU420068) optimum culture conditions were used as described in our previous study (Patel et al. 2009). At the end of fermentation cycle the content from the flasks were squeezed through muslin cloth and the filtrate obtained was centrifuged at 10,000 rpm for $10 \mathrm{~min}$ at $4{ }^{\circ} \mathrm{C}$. The supernatant thus obtained was subjected to the total protein precipitation with ammonium sulphate in the range of 0-75\% saturation. Dialysis was performed against $100 \mathrm{mM}$ sodium acetate $(\mathrm{pH} 4.5)$.

Purification of laccase by column chromatography

The purification was carried out with the help of AKTA purifier, Amersham Biosciences (USA). The dialyzed sample was applied to a DEAE-Sepharose column $(1 \times 15 \mathrm{~cm})$ previously equilibrated with $50 \mathrm{mM} \mathrm{Na}$ phosphate buffer ( $\mathrm{pH}$ 6.0) (Buffer-A). Other mobile phase was $50 \mathrm{mM}$ Na-phosphate buffer with $1 \mathrm{M} \mathrm{NaCl}$ (pH 6.0) (Buffer-B). The protein samples $(5 \mathrm{ml})$ were eluted with a gradient elution system in three steps: Step 1: $80 \%$ of
Buffer A and $20 \%$ of Buffer B was run for 75 min. Step 2: $20 \%$ of Buffer A and $80 \%$ of Buffer B was run for 80 min. Step 3: $100 \%$ of the Buffer B was run for 60 min. Re-equilibration of column after purification was carried out with $100 \%$ of Buffer A (Xiao et al. 2004).

Enzyme activity

\section{Laccase}

Laccase activity (E.C. 1.10.3.2) was determined by measuring the oxidation of ABTS. Increase in absorbance for 3 min was measured spectrophotometrically (Elico BL198, Hyderabad, India) at $420 \mathrm{~nm}$ (Niku et al. 1990). The reaction mixture contained $100 \mu \mathrm{l}$ of $50 \mathrm{mM}$ ABTS and $800 \mu \mathrm{l}$ of $20 \mathrm{mM}$ Na-acetate buffer ( $\mathrm{pH} 4.5)$ and $100 \mu \mathrm{l}$ of appropriately diluted enzyme extract. One unit of enzyme activity was defined as amount of enzyme that oxidized $1 \mu \mathrm{M}$ of substrate per min at room temperature.

\section{Enzyme characterization}

\section{Molecular weight determination}

The dialyzed sample of laccase was subjected to denaturing and non-denaturing PAGE on $12 \%$ gel. SDS-PAGE was performed to determine sample purity and approximate molecular mass of laccase. The approximate molecular mass of the laccase was determined by calibration against broad range molecular weight markers (BioRad), which contained the proteins phosphorylase $\mathrm{B}(97.4 \mathrm{kDa})$, bovine serum albumin (66 kDa), ovalbumin (43 kDa), carbonic anhydrase (29 kDa), soybean trypsin inhibitor $(20.1 \mathrm{kDa})$, and lysozyme (14.3 kDa). Non-denaturing PAGE was performed to ascertain which protein correlated to laccase activity. To ascertain accurate molecular weight of purified laccase matrix-assisted laser desorption/ionization-time of flight (MALDI-TOF) was performed.

\section{Activity staining}

Activity staining for laccase was performed with ABTS as the substrate. Non-denaturing (Native-PAGE) gels were allowed to stand in $100 \mathrm{ml}$ of sodium acetate buffer (100 mM, pH 4.5) with $1 \mathrm{ml}$ of $10 \mathrm{mM}$ ABTS for 20-30 min. Laccase activity spots were indicated by the development of a green colored band.

\section{Determination of $\mathrm{pI}$}

Analytical isoelectric focusing on polyacrylamide gel (IEFPAGE) in the range 2.5-7.0 was performed on a Mini-IEF apparatus (Biorad, Richmond USA). The $\mathrm{pH}$ gradient was 
measured by using the following standards: human carbonic anhydrase $(\mathrm{p} I=6.55)$, bovine carbonic anhydrase $(\mathrm{p} I=5.88), \beta$-glucosidase $(\mathrm{p} I=5.20)$, soybean trypsin inhibitor $(\mathrm{p} I=4.50), \quad$ glucose oxidase $(\mathrm{p} I=4.15)$, amyloglucosidase $(\mathrm{p} I=3.50)$ and pepsinogen $(\mathrm{p} I=2.80)$.

\section{$N$-terminal sequencing and MALDI-TOF analysis}

The N-terminal sequencing was performed on Applied Biosystems (Precise Protein Sequencer Company) and matrix-assisted laser desorption/ionization-time of flight (MALDI-TOF) using Axima-CFR, Kartos Analytical (A Shimadzu Group Company) at IIT, Powai (Mumbai, India).

\section{Effect of different $\mathrm{pH}$}

The $\mathrm{pH}$ optima was determined over a range of $\mathrm{pH}$ 2-9. The $\mathrm{pH}$ optima of an enzyme was performed by using three different buffer systems comprising of: $100 \mathrm{mM}$ sodium acetate buffer ( $\mathrm{pH} 2.0-5.0) ; 100 \mathrm{mM}$ sodium phosphate buffer $(\mathrm{pH}$ 6.0-8.0) and $100 \mathrm{mM}$ Tris- $\mathrm{HCl}$ buffer $(\mathrm{pH}$ 8.0-9.0).

\section{Optimum temperature and thermal stability}

The effect of temperature on laccase activity was determined by oxidation of ABTS for $3 \mathrm{~min}$ at temperature ranging from $20-80{ }^{\circ} \mathrm{C}$ with an interval of $10^{\circ} \mathrm{C}$. The thermal stability was determined under same assay conditions in a temperature range of $20-80{ }^{\circ} \mathrm{C}$. Sodium acetate buffer ( $\mathrm{pH} 4.5,100 \mathrm{mM}$ ) was used for all the reactions, at optimum $\mathrm{pH}$ of laccase.

\section{Enzyme kinetics}

Four different substrates (ABTS, Guaiacol; DMP and $O$-dianisidine) that could be oxidized by laccase were used in varying concentrations $(20-100 \mathrm{mM})$. Apparent $K_{\mathrm{m}}$ was determined by Lineweaver-Burk plot for laccase with various substrates used.

\section{Inhibition studies}

Three different potential inhibitors sodium azide $\left(\mathrm{NaN}_{3}\right)$ cysteine and ethylene diamine tetra acetic acid (EDTA) were evaluated to test the inhibition properties on laccase.

\section{Metal content of laccase}

The purified laccase was checked for presence of different metal ions such as copper, iron and zinc by inductively coupled plasma spectroscopy-optical emission spectroscopy (ICP-OES) (Perkin Elmer, USA, Optima-3300 RL).
Absorption spectrum of laccase

The UV-visible spectrum of the purified laccase was determined at wavelengths between 200 and $700 \mathrm{~nm}$ at room temperature in $100 \mathrm{mM}$ acetate buffer ( $\mathrm{pH} 4.5)$ using a UV-visible spectrophotometer (ELICO, BL-198, Hyderabad, India).

\section{Results and discussion}

\section{Purification}

Optimum culture conditions were used for the production of laccase from P. ostreatus HP 1 (Genbank Accession No. EU420068) as described in our earlier study (Patel et al. 2009). The crude filtrate obtained was then subjected to the purification process. The complete precipitation of laccase from the crude filtrate required at least $75 \%$ saturation of the supernatant with ammonium sulphate. After the application of dialysis further purification process was carried out with DEAE-sepharose column $(1 \times 15 \mathrm{~cm})$, using gradient elution in three different steps, each comprising combination of two different buffers. Before the first step, the flow through of the column was observed for the first $60 \mathrm{~min}$, which is the removal of the unbounded material from the column. No laccase activity was observed in any of the fractions collected in the first step. A sharp protein peak with laccase activity was obtained in second step, Maximum recovery of laccase occurred in this step. Negligible loss of laccase activity $\left(0.031 \mathrm{U} \mathrm{ml}^{-1}\right)$ was observed in the 3rd step and was therefore not taken into any consideration. At last, the purified enzyme obtained was subject to freeze drying. This strategy resulted in 13.13 -fold purification with $77.63 \%$ yield of laccase enzyme. Sahay et al. (2008) reported 10.71-fold purification with $3.46 \%$ yield from Pleurotus sajor-caju MTCC 141. Diaz et al. (2010) reported 32.7 and 31.2 purification fold with 2.2 and $2.6 \%$ yield for Lac I and Lac II isoenzymes from Coriolopsis rigida. Comparing to other studies, the results obtained were quite encouraging. However, Junghanns et al. (2009) reported 117-fold purification of laccase enzyme with very low yield of $0.95 \%$.

\section{Characterization of purified laccase}

The purified laccase was further analyzed and characterized by native-PAGE, SDS-PAGE, MALDI-TOF, IEF, ICP-OES, N-terminal sequencing and UV-visible spectrum analysis. The non-denaturing gel (native-PAGE) with duplicate sets of samples was bisected and half was stained with silver nitrate, and the other half was stained with ABTS to determine which band correlated to laccase 
activity (Fig. 1a). Purified laccase from P. ostreatus HP-1 was shown to be homogeneous with single protein band according to the size with SDS-PAGE (Fig. 1a) as well as with native-PAGE (Fig. 1a). The relative molecular mass of the laccase protein was determined, and was found to be more than $68,000 \mathrm{Da}$, and it was further confirmed with MALDI-TOF analysis which revealed that the protein had a molecular weight of 68,420 Da (Fig. 1b). Zymogram analyses were performed for both, the denaturing as well as non-denaturing electrophoresis gels. The activity staining of laccase, with ABTS as substrate, revealed that the single protein band corresponded with activity of the laccase. The relative molecular mass of $P$. ostreatus HP-1 laccase compares well with the $68,000 \mathrm{Da}$ laccase of $P$. sanguineus reported by Gonzalez et al. (2008). The relative molecular mass of laccase purified from Lentinula edodes and Phoma sp. reported to be 58.5 and $75.6 \mathrm{kDa}$, respectively (Junghanns et al. 2009; Ulrich et al. 2005).

The isoelectric point $\mathrm{p} I$ of purified laccase was found to be 3.5 which is more acidic; however, $\mathrm{p} I$ values can vary widely, from 2.9 to 6.9 (Baldrian 2006). The concentrated enzyme solution was slight yellow brown in color. Certain laccases have been found to be yellow or yellow brown rather than the blue color that is expected for laccases. Yellow laccases and blue laccases from the same organism had similar copper contents. It was proposed that yellow laccases, under normal aerobic conditions, did not maintain their copper centers in the oxidised state of resting enzymes. The binding of low molecular mass phenolic material from lignin degradation could contribute to such a change of enzymatic property (Leontievsky et al. 1997).

Presence of metal ions in purified laccase

It has been also found that laccases that do not have the blue color, can have copper, zinc and iron atoms instead of the classical four copper atoms. The ICP analysis of enzyme sample revealed the presence of two other metals, iron and zinc. The ratio for the metal ions detected by ICP was found to be 1:1:2 stoichiometry of copper/iron/zinc. Similar results were reported for the laccase isoenzyme POXA1 obtained from P. ostreatus (Palmieri et al. 1993).

$\mathrm{N}$-terminal sequence analysis

The terminal amino acid sequence of laccase from $P$. ostreatus HP-1 was when compared with other Pleurotus spp. (Table 2). It has been found that the N-terminal sequence of purified laccase did not show any similarity with those of the laccases from other Pleurotus spp. This may be due to truncated amino acids obtained during sequencing. However, from the present investigation it is difficult to draw a conclusion on such dissimilarity of $\mathrm{N}$-terminal (a)
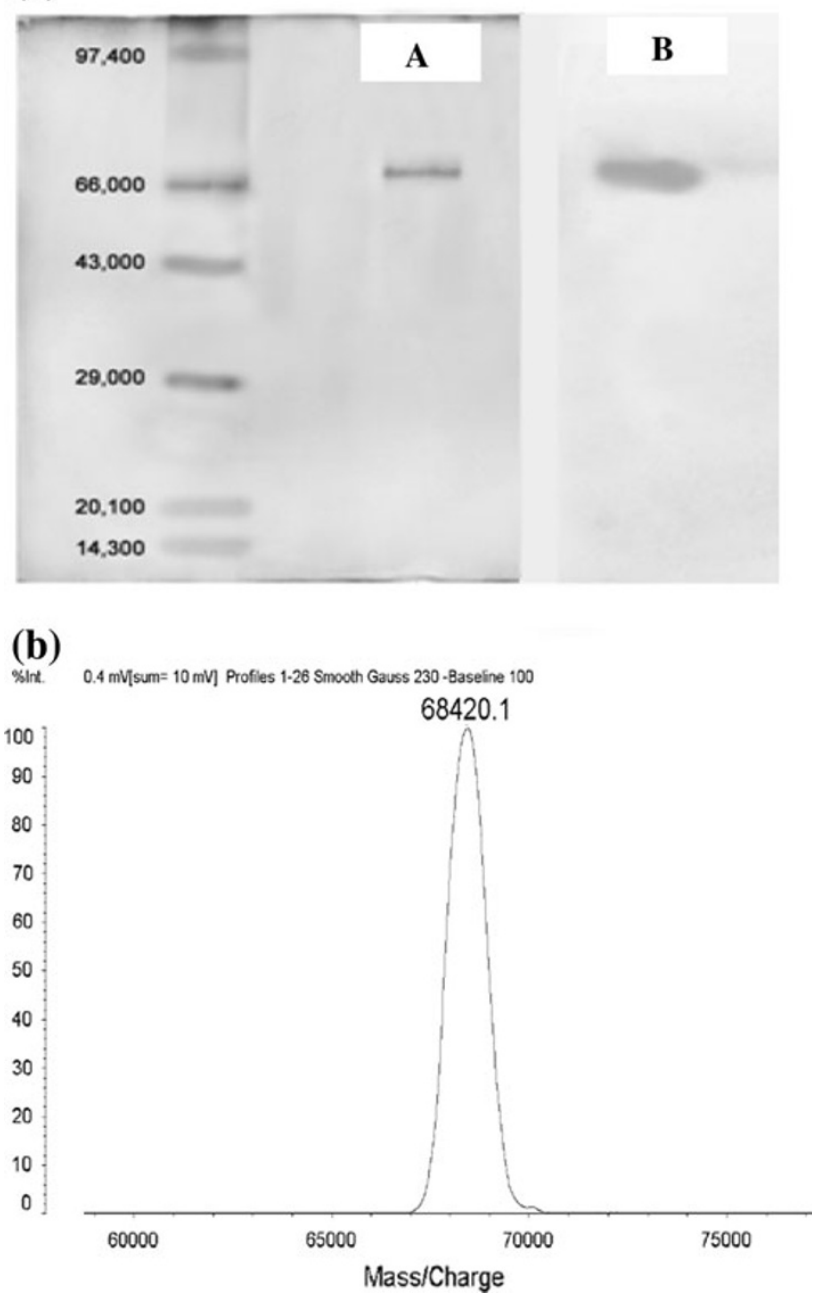

Fig. 1 a The SDS-PAGE $(A)$ indicating single band of protein with molecular weight of approximately 66,000 Da which corresponds to the single band showing blue color of laccase activity in activity staining $(B)$. b The peak of MALDI-TOF indicating the actual molecular weight of the purified laccase

sequence of laccase from $P$. ostreatus HP-1 with other Pleurotus spp.

Spectrophotometric analysis of purified laccase

The absorption spectrum of laccase in the range 200-700 nm was also performed. An absorption maximum at $610 \mathrm{~nm}$ shows the characteristic of fungal laccase copper atom type I. Which compares well with laccase enzyme from Paraconiothyrium variabile showed a peak around $600 \mathrm{~nm}$, indicating the presence of copper atom type I (Forootanfar et al. 2011). The type 3 binuclear copper was absent in laccase of $P$. ostreatus HP-1 as there was no shoulder at $330 \mathrm{~nm}$. The type 3 binuclear copper in present in both the laccases of Pleurotus eryngii (Munoz et al. 1997). This combination of molecular features (unusual 
color and absence of the in the absorption spectrum) were found previously in 'yellow' laccases of the fungi Panus tigrinus, Phlebia radiata, and Phlebia tremellosa (Leontievsky et al. 1997). This was again an evidence of this laccase as 'yellow' other than the typical 'blue' laccase found in many Pleurotus spp.

\section{Kinetic properties of laccase}

Values of $K_{\mathrm{m}}$ and $K_{\text {cat }}$ of different laccases widely vary for the same substrate. The majority of laccasses combine a high affinity for ABTS and syringaldazine with a high catalytic constants, where as guaiacol and 2,6-dimethoxyphenol are oxidized markedly slower and the corresponding Michaelis constants are significantly higher (Table 1). The $K_{\mathrm{m}}$ values (Table 1 ) of laccase from $P$. ostreatus HP-1 towards the various substrates indicated that the binding affinity towards the different substrates were in the order: $O$-dianisidine $>$ ABTS $>$ Guaiacol $>$ DMP. In contrast the affinity $\left(K_{\mathrm{m}}\right.$ value) of the Myrioconium sp. laccase towards typical laccase substrates follows the rank order syringaldazine $>$ DMP $>$ ABTS, where DMP is more specific substrate than ABTS for laccase (Martin et al. 2007). The values reported for the parameter, $K_{\text {cat }}$, is a representation of the rate the catalytic process (Table 2).

The ratio $K_{\text {cat }} / K_{\mathrm{m}}$ gives an indication of each enzyme and therefore allows us to compare the efficiencies of the different enzymes. Table 1 shows that ABTS is most efficiently oxidized by laccase as it exhibits the highest values for $K_{\text {cat }} / K_{\mathrm{m}}$ ratio for all the substrates studied. The guaiacol was the second efficient substrate oxidized by the laccase but it was less reactive towards $O$-dianisidine and DMP. The overall order of efficiency of enzyme for different substrates studied can be given as ABTS $>$ guaiacol $>$ $O$-dianisidine $>$ DMP. The $K_{\text {cat }}$ value for ABTS (244.32 $\mathrm{s}^{-1}$ ) was lower than those found for several other white-rot fungi laccases, such as those of Trametes multicolor $\left(510 \mathrm{~s}^{-1}\right)$, Coriolus hirsutus $\left(260 \mathrm{~s}^{-1}\right)$ but higher than those reported Picnoporus cinnabarinus $\left(920 \mathrm{~min}^{-1}\right.$ ) and Phellinus ribis $\left(8.0 \times 10^{4} \mathrm{~min}^{-1}\right)$ (Leitner et al. 2002; Shin and Lee 2000; Min et al. 2001).

Inhibition study

The activity of laccases is inhibited by various organic and inorganic compounds (Morozova et al. 2007). Anions such as the halides, azide, cyanide and hydroxide bind to the types 2 and 3 copper atoms of laccases, which disrupts the electron transfer system, resulting in enzyme inhibition (Gianfreda et al. 1999). Three potential inhibitors (Sodium azide, EDTA and cysteine) were evaluated to check the inhibition properties of laccase. The EDTA and cysteine inhibited the laccase to a lesser extent. The results shows the different inhibition constants $\left(K_{\mathrm{i}}\right)$ and type of inhibition observed in this study. The sodium azide is an inhibitor of metallo-enzymes showed 'non-competitive' inhibition which was classified as same $K_{\mathrm{m}}$ for both i.e. with inhibitor and without inhibitor and decrease in $V_{\max }$. This observation was not consistent with the findings of Heinzkill et al. (1998) who noted competitive inhibition with sodium azide for laccase from four different species of fungi, and average $K_{\mathrm{i}}$ of approximately $1 \mu \mathrm{M}$. The $K_{\mathrm{i}}$ obtained for the $P$. ostreatus HP-1 was in the region of $0.0165 \mathrm{mM}$, indicating that the presence of the sodium azide is less inhibitory to laccase. The cysteine showed 'competitive non-competitive or mixed inhibition' because the pattern lies between competitive and non-competitive inhibition of laccase, where a series of line intersecting between $y$ axis intercept and $x$ axis intercept in Lineweaver-Burk Plot. Although EDTA exhibited the uncompetitive type of inhibition classified as decrease in both $K_{\mathrm{m}}$ and $V_{\max }$. In the present study, the oxidase inhibitor sodium azide caused

Table 1 A comparison of kinetic properties of purified laccase from Pleurotus ostreatus HP-1 with other reported Pleurotus spp.

\begin{tabular}{llllll}
\hline Source of laccase & Substrate & $K_{\mathrm{m}}(\mathrm{mM})$ & $K_{\mathrm{cat}}\left(\mathrm{s}^{-1}\right)$ & $K_{\mathrm{cat}} / K_{\mathrm{m}}\left(\mathrm{mM}^{-1} \mathrm{~s}^{-1}\right)$ & References \\
\hline Pleurotus ostreatus HP-1 & ABTS & 46.51 & 244.32 & 5.25 & Present study \\
Pleurotus ostreatus HP-1 & DMP & 400 & 208.33 & 0.52 & Present study \\
Pleurotus ostreatus HP-1 & Guaiacol & 100 & 208.33 & 2.08 & Present study \\
Pleurotus ostreatus HP-1 & O-dianisidine & 23.52 & 43.85 & 1.86 & Present study \\
Pleurotus ostreatus POXA1 & ABTS & 0.09 & 5,833 & 64,815 & Palmieri et al. (1993) \\
Pleurotus ostreatus POXC & Guaiacol & 1.2 & 2.5 & 2.1 & Palmieri et al. (1993) \\
Pleurotus pulmunarius Lcc2 & ABTS & 0.210 & 1,520 & 7,238 & De-Souza and Peralta (2003) \\
Pleurotus pulmunarius Lcc2 & Guaiacol & 0.550 & 310 & 563 & De-Souza and Peralta (2003) \\
Pleurotus pulmunarius Lcc2 & Syringaldazine & 0.012 & 654 & 54,500 & De-Souza and Peralta (2003) \\
Pleurotus florida & O-dianisidine & 0.45 & $1.86 \times 10^{6}$ & $4.13 \times 10^{7}$ & Das et al. (2001) \\
Pleurotus florida & Guaiacol & 2.81 & $9.3 \times 10^{5}$ & $3.31 \times 10^{5}$ & Das et al. (2001)
\end{tabular}

$K_{\mathrm{m}}=$ Michaelis constant, $K_{\text {cat }}=$ turnover number, $K_{\text {cat }} / K_{\mathrm{m}}=$ measures of catalytic efficiency 
Table 2 Comparison of $\mathrm{N}$-terminal amino acid sequence of laccase from Pleurotus ostreatus HP-1 with other Pleurotus spp.

\begin{tabular}{lll}
\hline Organism & N-Terminus amino acid sequence & References \\
\hline $\begin{array}{l}\text { Pleurotus ostreatus HP-1 } \\
\text { Pleurotus florida }\end{array}$ & S L W V A L W M S A - - & Present study \\
$\begin{array}{l}\text { Pleurotus ostreatus } \\
\text { Pleurotus eryngii }\end{array}$ & --- P A G N M Y I V N E & Das et al. (2001) \\
L1 & A I G P A G N M Y I V N E & Palmieri et al. (1993) \\
L2 & A - K K L - D F H I I N N & \\
Pleurotus ostreatus POX1 & A T K K L - D F H I I N N & Munoz et al. (1997) \\
\hline
\end{tabular}

complete inhibition of laccase at concentration of $0.05 \mathrm{mM}$. The study by Iyer and Chattoo (2003) reported the laccase from rice blast fungus Mannaporthe grisea was inhibited up to $99 \%$ at $1 \mathrm{mM}$ concentration of sodium azide. The possible reason of laccase enzyme inhibition is the binding of $\mathrm{NaN}_{3}$ to the metal ion sites of laccase, that affect internal electron transfer, which ultimately affect the overall oxidation process catalyzed by laccase (Ryan et al. 2003). Chelating agent EDTA inhibited the enzyme only at higher concentrations which was in accordance with the earlier study by De-Souza and Peralta (2003). The EDTA was not an efficient inhibitor of laccase, which was in line with the earlier studies by other researchers (Heinzkill et al. 1998; Liu et al. 2010).

\section{Temperature stability}

Temperature stability of laccase was studied at various temperatures for various time periods in $100 \mathrm{mM}$ acetate buffer $\mathrm{pH}$ 4.5. The enzyme was quite stable at $-4{ }^{\circ} \mathrm{C}$ for months. When laccase was incubated at $30{ }^{\circ} \mathrm{C}$, it was stable up to $18 \mathrm{~h}$ (Fig. 2). Purified laccase was quite stable at $40{ }^{\circ} \mathrm{C}$ for $5 \mathrm{~h}$ (Fig. 2). However, at $50{ }^{\circ} \mathrm{C}$ laccase was found stable for $10 \mathrm{~min}$ and considerable loss of activity was observed after $12 \mathrm{~min}$ (Fig. 2). The brief increase in the activity of the $P$. ostreatus HP-1 laccase after $10 \mathrm{~min}$ at $50{ }^{\circ} \mathrm{C}$ was probably due to the unfolding of the protein structure (Ryan et al. 2003). In the initial 15 min of incubation the half of the laccase activity was found to be lost at $60{ }^{\circ} \mathrm{C}$ (Fig. 2), whereas rapid inactivation of the enzyme was observed at $70{ }^{\circ} \mathrm{C}$ (Fig. 2). Comparable results of thermostability was also reported by Agaricus blazei laccase (Ulrich et al. 2005) and Cerrena unicolor LacC2 (Lisova et al. 2010). The laccase from P. ostreatus HP-1 showed its optimum activity at $50{ }^{\circ} \mathrm{C}$ which was quite similar to P. ostreatus (Palmieri et al. 1993) and $\mathrm{L}_{2}$ laccase enzyme from Pleurotus florida (Das et al. 2001). Laccase from $P$. ostreatus was almost fully active in the temperature range of $40-60{ }^{\circ} \mathrm{C}$ and showed half life of $30 \mathrm{~min}$ at $60{ }^{\circ} \mathrm{C}$ (Das et al. 2001). In the present study, the laccase was active in the temperature range of $40-70{ }^{\circ} \mathrm{C}$ with half life of $15 \mathrm{~min}$ at $60{ }^{\circ} \mathrm{C}$. Laccase was almost completely inactivated after $15 \mathrm{~min}$ at $70{ }^{\circ} \mathrm{C}$. Munoz et al. (1997) showed that the laccase I and II of Pleurotus eryngii retained 3 and $10 \%$ residual activity, respectively, at $60{ }^{\circ} \mathrm{C}$ after $30 \mathrm{~min}$. Gonzalez et al. (2008) reported $3.7 \%$ residual activity of Pycnoporous sanguineus laccase after incubation at $70{ }^{\circ} \mathrm{C}$ for $1 \mathrm{~h}$. In contrast Tong et al. (2007) reported Trametes sp. LacE with half life of $1.3 \mathrm{~h}$ at $60{ }^{\circ} \mathrm{C}$. The differences in the effect of different temperatures on laccase activity might be related to, some extent, to the number of disulphide bonds in the molecule. In addition, the thermal dissociation might also participate in the temperature profile (Xu et al. 1996).

\section{Effect of different $\mathrm{pH}$}

The optimum $\mathrm{pH}$ for the majority of fungal lacasses found in the range of 3.0-4.0 when organic donors of hydrogen atoms are used as substrates, and the $\mathrm{pH}$ dependence curve is bell-shaped (Stoilova et al. 2010) and such profile of laccase activity on oxidation of phenolic compounds is caused by two effects. On one hand, with increase in the $\mathrm{pH}$ of the solution, ionization potential of phenolic

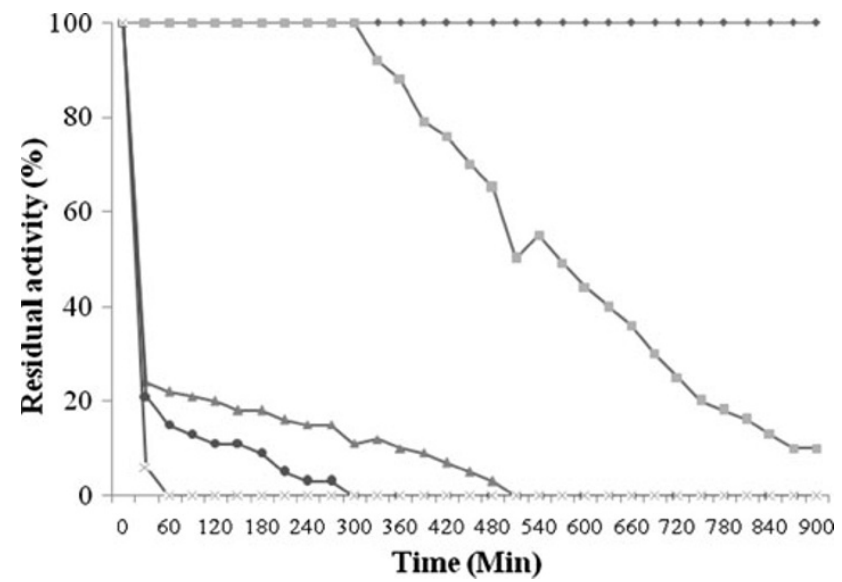

Fig. 2 Effect of different temperature $30{ }^{\circ} \mathrm{C}$ wide diamond, $40{ }^{\circ} \mathrm{C}$ square, $50{ }^{\circ} \mathrm{C}$ triangle, $60{ }^{\circ} \mathrm{C}$ diamond and $70{ }^{\circ} \mathrm{C}$ cross on stability of laccase 
compounds decreases with as a result of formation of phenolate anion that has to enhance the rate of the enzymatic reaction. On the other hand, with increase in the $\mathrm{pH}$ of the solution the rate of laccase catalyzed reactions decreases at the cost of $-\mathrm{OH}$ binding with the T2/T3 site of the enzyme.

The purified enzyme was tested for its characteristics under different $\mathrm{pH}$ conditions. The $\mathrm{pH}$ optima of purified laccase on different substrates were determined over a range of $\mathrm{pH}$ starting from 2.0 to 9.0. The $\mathrm{pH}$ profile of $P$. ostreatus HP-1 laccase showed maximum activity at $\mathrm{pH}$ 4.5 when ABTS was used as a substrate (Fig. 3). Pycnoporus cinnabarinus laccase showed to have optimum $\mathrm{pH}$ of 4 for ABTS (Eggert et al. 1996). P. ostreatus HP1 laccase exhibited maximum activity at $3.5 \mathrm{pH}$ for both DMP and $O$-dianisidine (Fig. 3). Cerrena unicolor VKMF-3196 LacC2 demonstrated maximum activity at $\mathrm{pH} 3.8$ for DMP (Lisova et al. 2010), which is quite comparable with our results. Whereas for guaiacol $\mathrm{pH} 5.5$ was found to be optimum for laccase activity (Fig. 3). Laccase from Phoma sp. UHH 5-1-03 showed optimum $\mathrm{pH} 5.0$ when guaiacol was used as a substrate (Junghanns et al. 2009). A gradual decrease in the oxidation rate of various substrates was observed at higher $\mathrm{pH}$, which may be due to ionization of critical amino acids (Asp and Glu), indicating that the enzyme was inactive at higher $\mathrm{pH}$ (Salony et al. 2006). The highest activity of $P$. ostreatus laccases with respect to $\mathrm{pH}$ profile also varied with the changes of substrates (Palmieri et al. 1993). The $\mathrm{pH}$ optima for activity depends on the substrate selected. For example, P. ostreatus has a $\mathrm{pH}$ optimum range of 3-3.5 for the oxidation of ABTS, but when the $\mathrm{pH}$ optima is determined for guaiacol and syringaldazine it is 5.6 and 6.7, respectively (Palmieri et al. 1993). This can be attributed to the reaction mechanism of the laccase. Whether the mechanism involves abstraction of an electron or hydrogen. The latter will be affected by changes in $\mathrm{pH}$. As well as, the reaction depends on the redox potential of the substrate. The $\mathrm{pH}$ affects the ionization state of the substrate and therefore affects its ability to act as a reducing substrate (Majcherczyk et al. 1999).

\section{Conclusion}

The laccase from $P$. ostreatus HP-1 was purified to apparent electrophoretic homogeneity with high protein recovery. The improved catalytic properties of laccase, such as the high affinity for its substrate and relatively high turnover numbers, especially for the oxidation of ABTS, indicate that this enzyme may prove to be highly competitive for industrial application. The specificity constant $\left(k_{\mathrm{cat}} / K_{\mathrm{m}}\right)$, which takes into consideration both the specificity of the laccase for its substrate $\left(K_{\mathrm{m}}\right)$ as well as the

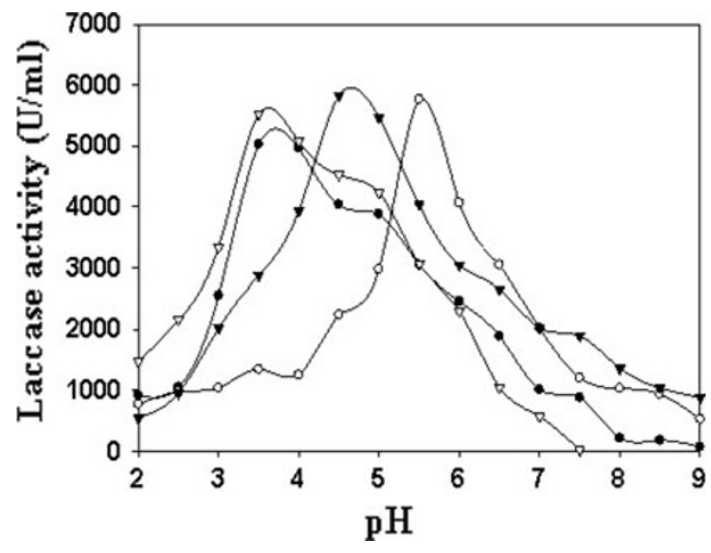

Fig. 3 Effect of different $\mathrm{pH}$ of the buffer on oxidation of different substrates by purified laccase. filled circle, open circle-dianisidine $\left(\mathrm{U} \mathrm{ml}^{-1}\right)$, open circle guaiacol $\left(\mathrm{U} \mathrm{ml}^{-1}\right)$, inverted filled triangle ABTS $\left(\mathrm{U} \mathrm{ml}^{-1}\right)$, inverted open triangle DMP $\left(\mathrm{U} \mathrm{ml}^{-1}\right)$

catalytic efficiency $\left(k_{\text {cat }}\right)$, was different to the specificity constant of "white" laccase from P. ostreatus. Owing to these improved catalytic properties, the broad $\mathrm{pH}$ range for the oxidation of ABTS, and production of this laccase in sufficient yields may provide a valuable alternative enzyme source for industrial applications. The sequence information obtained from purified laccase produced by $P$. ostreatus HP-1 did not showed any similarity to that of laccase from other Pleurotus spp. However, such kind of dissimilarity of N-terminal sequence could not be explained at this time. If combination made between the data obtained from visual observation, biochemical properties and other molecular feature gave confirmation of this laccase as "Yellow" laccase found in many Pleurotus spp.

Acknowledgments Mayur Gahlout wishes to thank the Department of Biotechnology (DBT), New Delhi, India for providing Junior Research Fellowships. The financial support received from the Department of Biotechnology, Ministry of Science and Technology, Government of India, New Delhi, India, is highly acknowledged.

Conflict of interest The authors declare that they have no conflict of interest.

Open Access This article is distributed under the terms of the Creative Commons Attribution License which permits any use, distribution, and reproduction in any medium, provided the original author(s) and the source are credited.

\section{References}

Alberts JF, Gelderbolm WCA, Botha A, Vanzyl WH (2009) Degradation of aflatoxin B1 by fungal laccase enzymes. Int $\mathbf{J}$ Food Microbiol 135:47-52

Baldrian P (2006) Fungal laccases_occurrence and properties. FEMS Microbiol Rev 30:215-242

Dahiya JS, Singh DNP (1998) Characterization of laccase produced by Coniothyrium minitans. J Basic Microbiol 38:349-359 
Das N, Chakraborty TK, Mukherjee M (2001) Purification and characterization of a growth regulating laccase from Pleurotus florida. J Basic Microbiol 41:261-267

De-Souza CGM, Peralta M (2003) Purification and characterization of the main laccase produced by the white-rot fungus Pleurotus pulmunarius on wheat bran solid medium. J Basic Microbiol 43:278-286

Diaz R, Mario C, Saparrat N, Jurado M, Romera GI, Ocampo JA, Martinz MJ (2010) Biochemical and molecular characterization of Coriolopsis rigida laccases involved in transformation of the solid waste from olive oil production. Appl Microbiol Biotechnol 88:133-142

Eggert C, Temp U, Dean J, Eriksson K (1996) A fungal metabolite mediated degradation of non-phenolic lignin structures and synthetic lignin by laccase. FEBS Lett 391:144-148

Forootanfar H, Faramarzi MA, Shahverdi AR, Yazdi MT (2011) Purification and biochemical characterization of extracellular laccase from the ascomycete Paraconiothyrium variabile. Bioresour Technol 102:1808-1814

Gianfreda L, Xu F, Bollag JM (1999) Laccases: a useful group of oxidoreductive enzymes. Bioremed J 3:1-25

Gonzalez ED, Vallejo OV, Anaya CM, Sanchez MM, Gonzalez MC, Palomares LA, Mallol JF (2008) Production of two novel laccase isoforms by a thermotolerant strain of Pycnoporous sanguineus isolated from an oil-polluted tropical habitat. Int Microbiol 11:163-169

Heinzkill M, Bech L, Halkier T, Schneider P, Anke T (1998) Characterization of laccases and peroxidases from wood-rotting fungi (family Coprinaceae). Appl Environ Microbiol 64:1601-1606

Iyer G, Chattoo BB (2003) Purification and characterization of laccase from the rice blast fungus Magnaporthe grisea. FEMS Microbiol Lett 227:121-126

Junghanns C, Pecyna MJ, Bohm D, Jehmlich N, Martin C, Bergen MV, Schauer F, Hofrichter M, Schlosser D (2009) Biochemical and molecular genetic characterisation of a novel laccase produced by the aquatic ascomycete phoma sp. UHH 5-1-03. Appl Microbiol Biotechnol 84:1095-1105

Leitner C, Hess J, Galhupm C, Ludwig R, Nidetzky B, Kulbe KD, Haltrich D (2002) Purification and characterization of a laccase from the white-rot fungus Trametes multicolor. Appl Biochem Biotechnol 98:497-507

Leonowicz A, Szklarz G, Wojtas WM (1985) The effect of fungal laccase on fractionated lignosylphonates (Peritan Na). Phytochemistry 24:393-396

Leontievsky A, Myasoedova N, Pozdnyakova N, Golovleva L (1997) 'Yellow' laccase of Panus tigrinus oxidises non-phenolic substrates without electron-transfer mediators. FEBS Lett 413:446-448

Lisova ZA, Lisova AV, Leontievsky AA (2010) Two laccase isoforms of the basidiomycete Cerrena unicolor VKMF-3196. Induction, isolation and properties. J Basic Microbiol 50:72-82

Liu Z, Zhang D, Hua Z, Li J, Du G, Chen J (2010) Improvement of laccase production and its properties by low-energy ion implantation. Bioprocess Biocyst Eng 33:639-646

Lu L, Zhao M, Zhang BB, Yu SY, Bain XJ, Wang Y (2007) Purification and characterization of laccase from Pycnoporus sanguineus and decolorization of an anthraquinone dye by the enzyme. Appl Microbiol Biotechnol 74:1232-1239

Majcherczyk A, Johannes C, Hutterman A (1999) Oxidation of aromatic alcohols by laccase from Trametes versicolor mediated by the 2,2'-azinobis-( 3 ethylbenzthiazoline-6-sulphonic acid) cation radical and dication. Appl Microbiol Biotechnol 51: 267-276

Majeau JA, Brar SK, Tyagi RD (2010) Laccase for removal of recalcitrant and emerging pollutants. Bioresour Technol $101: 2331-2350$
Martin C, Pecyna M, Kellener H, Jehmlich N, Junghanns C, Benndorf D, Bergen MV, Schlosser D (2007) Purification and biochemical characterization of a laccase from the aquatic fungus Myrioconium sp. UHH 1-13-18-4 and molecular analysis of the laccase encoding gene. Appl Microbiol Biotechnol 77:613-624

Min KL, Kim YH, Lim YW, Jung HS, Hah YC (2001) Characterization of a novel laccase produced by the wood-rotting fungus Phellinus ribis. Arch Biochem Biophy 392:279-286

Morozova OV, Shumakovich GP, Gorbacheva MA, Shleev SV, Yaropolov AI (2007) Review: "blue" laccases. J Basic Microbiol 72:1136-1150

Munoz C, Guillen F, Martinez AT, Martinez MJ (1997) Laccase isoenzymes of Pleurotus eryngii: characterization, catalytic properties and participation in activation of molecular oxygen and $\mathrm{Mn}^{2+}$ oxidation. Appl Environ Microbiol 63:2166-2174

Niku PML, Raaska L, Itavaara M (1990) Detection of white rot fungi by a non-toxic stain. Mycol Res 94:27-31

Palmieri G, Giardina P, Marzullo L, Desiderio B, Nitti B, Cannio R, Sania G (1993) Stability and activity of phenoloxidase from lignolytic fungus. Pleurotus ostreatus. Appl Microbiol Biotechnol 39:632-636

Patel H, Gupte A, Gupte S (2009) Effect of different culture conditions and inducer on production of laccase by a basidiomycetes fungal isolate Pleurotus ostreatus HP-1. Biores 4(1):268-284

Rittstieg K, Suurnakki A, Suortti T, Kruus T, Guebitz GM, Buchert J (2003) Polymerization of guaiacol and a phenolic beta-O-4substructure by Trametes hirsuta laccase in the presence of ABTS. Biotechnol Prog 19:1505-1509

Ryan S, Schnitzhofer W, Tzanov T, Cavaco PA, Gubitz GM (2003) An acid-stable laccase from sclerotium rolfsii with potential for wool dye decolorization. Enzyme Microb Technol 33:766-774

Sahay R, Yadav SSR, Yadav KDS (2008) Purification and characterization of extracellular laccase secreted by Pleurotus sajorсаju MTCC 141. Chin J Biotech 24:2068-2073

Salony S, Mishra V, Bisaria S (2006) Production and characterization of laccase from Cyathus bulleri and its use in decolourisation of recalcitrant textile dyes. Appl Microbiol Biotechnol 71:646-653

Shin KS, Lee YJ (2000) Purification and characterization of a new member of a laccase family from the white-rot Basidiomycetes Coriolus hirsutus. Arch Biochem Biophys 384:109-115

Slomczynski D, Nakas JP, Tanenbaum SW (1995) Production and characterization of laccase from Botrytis cinerea. Appl Environ Microbiol 61:907-912

Stoilova I, Krastanova A, Stanchev V (2010) Properties of crude laccase from Trametes versicolor produced by solid substrate fermentation. Adv Biosci Biotechnol 1:208-215

Tong P, Hong Y, Xiao Y, Zhang M, Tu X, Cui T (2007) High production of laccase by a new basidiomycete, Trametes sp. Biotechnol Lett 29:295-301

Ulrich R, Huong LM, Dung NL, Hofrichter M (2005) Laccase from the medicinal mushroom Agaricus blazei: production purification and characterization. Appl Microbiol Biotechnol 67:357-363

Xiao YZ, Chen Q, Hang J, Shi YY, Xiao YZ, Wu J, Hong YZ, Wang YP (2004) Selective induction, purification and characterization of a laccase isoenzymes from the basidiomycete Trametes sp. AH28-2. Mycologia 96:26-35

Xu F, Shin W, Brown SH, Wahleithner JA, Sundaram UM, Solomon EI (1996) A study of a series of recombinant fungal laccases and bilirubin oxidase that exhibit significant differences in redox potential, substrate specificity, and stability. Biochem Biophys Acta 1292:303-311 